\title{
La imagen del niño; su tratamiento legal
}

\author{
J. Siso Martín \\ Profesor de Deontología y Legislación Sanitaria. Facultad de Ciencias de la Salud. \\ Universidad Rey Juan Carlos. Madrid. España.
}

\begin{abstract}
Resumen
El derecho a la propia imagen es objeto de protección constitucional, junto con los derechos al honor y a la intimidad. Tal es la importancia que nuestro ordenamiento jurídico concede a este asunto. Hoy cobra especial relevancia, esta necesidad de protección, por la posibilidad de insertar imágenes personales en los modernos medios de comunicación, con ilimitadas posibilidades de difusión en el seno de las modernas tecnologías.

Se intensifica esta protección legal cuando la imagen corresponde a un menor, en cuyo caso intervienen mecanismos reforzados, como la normativa específica para estas personas y la existencia de un instrumento público concreto: la Fiscalía de Menores. Casos especiales, que gozan de cierta "indulgencia social", como el de los hijos de personas de pública notoriedad, no son, en realidad, legalmente diferentes al tratamiento general (salvo muy ligeras matizaciones), pues son menores a todos los efectos, si se encuentran en determinados tramos de edad, y con independencia de su filiación.
\end{abstract}

Palabras clave: Menor. Confidencialidad. Intimidad. Fiscalía. Telecomunicaciones.

The image of the child: its legal treatment

\section{Abstract}

The right to the own image is object of constitutional protection, like the rights to honor and intimacy. Such it is the importance that our juridical classification grants to this matter. Today it has a special relevancy due to the possibility of inserting personal images in the modern mass media, with unlimited possibilities of diffusion through the modern technologies. This legal protection is more intense when the image is that of a minor, in whose case reinforced mechanisms intervene, like specific regulation for these persons and the existence of a public instrument: the Minors' District attorney's office. Special cases, with certain "social indulgence", like that of the children of persons of public reputation are not legally different to the general treatment (except very light nuances), because if they are in certain sections of age, they are minor to all effects and with independence of their affiliation..

Key words: Minors. Confidentiality. Privacy. Public Defenders. Telecommunications.

Juan Siso Martín: paracelso.2000@gmail.com

El autor declara no presentar conflictos de intereses en relación con la preparación y publicación de este artículo. 


\section{Una reflexión previa}

De niños, mi generación, imaginábamos el futuro con robots caminando por la ciudad y platillos volantes en el cielo, pero nada de eso ha sucedido. El progreso tecnológico ha tenido una puntera manifestación, sin embargo, en aspectos que no podíamos imaginar. ¿Cómo podríamos suponer que fuera posible hablar, desde la playa, con alguien al otro lado del mundo? ¿De qué manera, concebir que seríamos capaces de enviar textos o imágenes a miles de kilómetros de distancia y recibirse allí, de inmediato? Recuerden ustedes el asesinato del presidente Kennedy, en 1963. Las imágenes del magnicidio de Dallas, tras su filmación, no estuvieron en España hasta días después. Había que procesar el revelado del celuloide, debía examinarlo la CÍA (naturalmente) y aún tenía que viajar una copia hasta nuestro país. Hoy viajan las imágenes en formato electrónico por el ciberespacio, en instantes, e incluso podemos ver "on-line" la propia filmación. Todos recordamos aún el horror de contemplar en directo la tragedia del 11-S en Nueva York, aunque podemos tener también la experiencia más grata, claro, de ver jugar a Gasol, también en directo, al otro lado del mundo.

Esta posibilidad de obtener y difundir información, sin apenas limitaciones en las coordenadas espacio y tiempo, puede suponer un grave compromiso sobre la privacidad e incluso la intimidad de las personas. El derecho a disponer y autorizar el tratamiento de la propia imagen es objeto de protección constitucional y cobra particular relieve cuando la imagen captada es la de un menor, como me voy a ocupar de mostrarles. El artículo 18.1 de nuestra Ley Fundamental recoge la garantía del derecho al honor, a la propia intimidad y a la propia imagen. El artículo 20 de esta misma norma, por su parte, especifica que el derecho a comunicar o recibir libremente información veraz, por cualquier medio de difusión, encuentra su límite en los derechos objeto de protección constitucional y especialmente en los antes mencionados del artículo 18. Esta decidida protección legal se intensifica respecto de los menores, como sujetos en tránsito hacia su madurez y desarrollo integral.

\section{La especial protección al menor}

El respeto a los derechos de los menores debe situarse en la base de los principios de nuestro sistema de convivencia social. La minoría de edad, en ese sentido, se concibe como aquella etapa de la vida caracterizada por la insuficiencia de la persona para propor- 
cionarse, a sí misma, los medios necesarios de protección en el ejercicio de los derechos personales. Se hacen precisos, por ello, mecanismos de protección, que en nuestro caso se desarrollan en ámbitos diferenciados: el espacio familiar (patria potestad o tutela), el institucional (protección de menores por la Administración) o el normativo (legislación en los distintos órdenes civil, administrativo, laboral o penal). Tiene especial relevancia, en lo que a la protección respecta, la figura del Ministerio Fiscal, como defensor de la esfera de privacidad de los menores, como les mostraré enseguida.

Ciñéndonos, ahora, a la minoría de edad civil, establecida tras el mandato constitucional y la reforma del Código Civil en la edad inferior a 18 años, haré una exposición de este asunto, bajo planteamientos jurídicos, con las necesarias precisiones, pero sin demasiados rigores de esa índole, consciente de que los destinatarios de estas líneas son personas ajenas al mundo del Derecho.

La protección legal alcanza a cualquier menor de edad que se encuentre en territorio nacional y en el caso de los ataques que puedan experimentar a sus derechos a la intimidad y a la propia imagen, cuentan con garantías legales adicionales por el hecho de que, al ser el sujeto pasivo, precisamente, un menor, se puede perturbar su correcto desarrollo psicofísico. La enumeración de las normas es larga y baste con mencionar que a la lista general hay que añadir la normativa específica en el terreno de los menores, entre la cual debo destacar: Ley 1/1996, Orgánica de Protección Jurídica del Menor, la Convención de Derechos del Niño, de noviembre de 1989, o la propia Carta Europea de Derechos del Niño, de julio de 1992.

\section{El papel del Ministerio Fiscal}

La Ley Orgánica 1/1982, de Protección Civil del Derecho al Honor, a la Intimidad Personal y Familiar y a la Propia Imagen aborda la protección especial, en estas materias, a los menores con el establecimiento de dos reglas:

- El consentimiento de los menores e incapaces a las intromisiones en su intimidad o propia imagen, deberá prestarse por ellos mismos si sus condiciones de madurez lo permiten, de acuerdo con la legislación civil.

- En los restantes casos, el consentimiento habrá de otorgarse por su representante legal, quien estará obligado a poner en conocimiento previo del Ministerio Fiscal el consentimiento proyectado. 
Si en el plazo de ocho días el Ministerio Fiscal se opusiere, resolverá el Juez.

De lo expuesto se desprende que el consentimiento del menor incapaz es jurídicamente irrelevante, pero también que el de su representante legal no es suficiente, por sí mismo, debiendo ser ratificado por el del Ministerio Fiscal. Es tan intenso este régimen de protección, como vemos, que desborda los límites de la patria potestad de los progenitores, erigiéndose en protección pública bajo responsabilidad estatal. No es ajeno este planteamiento al hecho de que, en algunas ocasiones, habrá de proteger al menor de sus representantes legales, que pueden tratar de beneficiarse de la utilización de la imagen de aquél.

Sin conocer este fundamento legal, muchos de ustedes son testigos diarios, sin embargo, de su aplicación. Podemos recordar las imágenes de menores con su rostro pixelado o con una franja negra cubriendo sus ojos, instrumentos ambos que impiden su identificación. Mediante estas acciones se pueden difundir sus imágenes sin acudir a la petición al Ministerio Fiscal, trámite que, en muchas ocasiones, retrasaría la difusión de la imagen perdiendo su carácter de primicia informativa y en cualquier caso entorpecería el curso periodístico.
Lo determinante es entender que el interés del menor, en el sentido que recoge la Ley Orgánica de Protección del Menor, es siempre preferente y que cuenta con instrumentos legales específicos para su protección.

Debo traer aquí, por su carácter ilustrativo, una sentencia (10 de noviembre 1998) de la Audiencia Provincial de Madrid, que condenó a Tele 5 S.A. a una indemnización, tras la acción emprendida por el Ministerio Fiscal. Con motivo del programa Misterios sin resolver se ocupó del caso de un niño abandonado en las puertas de un centro hospitalario, de quien se tomaron y difundieron imágenes e información sobre su estado de salud. La información era veraz, pero no había necesidad alguna de emitir la imagen ni la información aludida. El menor no podía, evidentemente, consentir, pero la entidad demandada tampoco buscó el consentimiento de quien legalmente podría haberlo prestado

El mismo tribunal, el 19 de abril de 2005, condenó a la revista Qué me dices a indemnizar a la madre de un menor por la indebida difusión de su imagen. La captación se hizo en el aeropuerto de Barajas, cuando el niño se encontraba en compañía de su madre, actriz de profesión, y con motivo de las desavenencias conyugales de aquélla. 
La condena se fundamenta en la consideración de que el carácter de famosa de la madre no transforma al menor en persona pública y notoria, ni hace necesaria la difusión de la imagen de alguien que es objeto de la máxima protección legal de su intimidad.

\section{El caso del menor maduro}

El concepto de mayoría de edad, con una fuerte carga civil, es cronológico, pero sobre él gravita muchas veces un correctivo. Es el de aquellos casos en los que sin haberse llegado a esta frontera temporal la persona, sin embargo, reúne los criterios de madurez emocional y vivencial suficientes para percibir la realidad y tomar decisiones sobre ella como si de un mayor de edad se tratara. No voy a entrar en los criterios a los que ha de acudirse para determinar cuándo nos encontramos ante un menor con esta condición de madurez, sino a las consecuencias de este hecho.

La sentencia de 26 de marzo de 2003 del Tribunal Supremo recoge el caso de un menor de 14 años de edad, a quien se tiene por maduro y se da valor a la autorización emitida por él mismo, respecto de la difusión de su imagen y manifestaciones. El Ministerio Fiscal entabló acción respecto de Tele 5 S.A. por la difusión de imágenes de un menor ob- jeto de una agresión. Se entrevistó al menor, en el Hospital 12 de Octubre, en su cama, contando cómo fue atacado a navajazos por otros menores, que le produjeron las heridas que le llevaron al centro sanitario. Fue entrevistada, también allí, la madre del menor, quien relató las desavenencias y desencuentros entre ambos en su vida diaria. Valora la sentencia el hecho de que en la toma de imágenes y la entrevista al menor se encontraba presente la madre y que al menor, por el conjunto de las circunstancias del caso, se le considera capaz de emitir consentimiento y por tanto, a efectos legales, se estaba entrevistando a dos personas adultas, con lo cual no cabe que prospere la acción del Ministerio Fiscal para otorgar protección a quienes no la necesitan.

\section{Unas precisiones necesarias}

Debo dejar mencionado que, cuando me refiero a la captación de imágenes de menores, estoy haciendo referencia a captación en situación de individualidad e identificación. Es decir, debe destacar el protagonismo del menor en la imagen captada y su posibilidad de identificación inequívoca. De este modo no cabe considerar a estos efectos la toma de imágenes de un menor integrado en un numeroso grupo de gente, en un aconteci- 
miento deportivo o entre la gente que espera un desfile, por ejemplo.

Esta protección alcanza, evidentemente, a cualquier tramo de edad en el que se sitúe un menor, pero se relativiza en la primera infancia. La imagen de un bebé es digna de dicha protección, pero los cambios fisonómicos que necesariamente se operarán en su persona, sobre la imagen obtenida del mismo, harán difícil la identificación en tiempo futuro y desdibujarán el perjuicio que entonces pueda ser invocado.

En otro sentido, la intromisión ilegítima del derecho a la propia imagen se produce por el solo hecho de publicar dicha imagen, fuera de las condiciones legales, con independencia del texto que la acompañe y que pudiendo ser, además, perjudicial al menor, sería objeto de otras acciones legales.

La difusión de la imagen, aun contando con el consentimiento de los progenitores del menor, si puede considerarse periudicial a los intereses de aquél, debe considerarse en principio ilegítima y por ello objeto de las medidas legales de protección pertinentes.

\section{La Instrucción 2/2006, de la Fiscalía General del Estado}

Comienza este interesante y esclarecedor instrumento normativo con la mención de que: el respeto por los derechos de los menores ha de ser seña de identidad de nuestro sistema de convivencia. En un detallado y abundante texto, cuya transcripción les ahorro, sitúa los siguientes criterios generales:

1. La Fiscalía no actuará de oficio, ni apoyará la demanda de padres o tutores contra un medio que difunda imágenes de un menor, cuando se trate de informaciones relativas al mundo infantil (...) siempre que las propias circunstancias que rodeen la información excluyan el periuicio para los menores y la imagen aparezca como accesoria de la información principal.

2. No habrá de considerarse, con carácter general, antijurídica la difusión de imágenes de menores en lugares públicos, cuando aparezcan de manera meramente casual o accesoria de la información principal (...) espectáculos públicos (...) siempre que tales actos no presenten aspectos negativos cuya asociación con la imagen del menor pudiera perjudicarle.

3. Si la difusión causal o accesoria de la imagen del menor se vincula a lugares, personas o actos con connotaciones negativas, habrán de utilizarse técnicas de distorsión de la imagen para evitar la identificación (...) (reportaje sobre barriada en la que se vende droga [...]).

4. La difusión de noticias veraces y de 
interés público que afecten a menores (...) y que pueda generarles un daño (...) estará amparada por el ordenamiento siempre que no sean estos identificados (empleo de [...] distorsión de imagen o de voz, utilización de iniciales [...]).

Habrá de evitarse no sólo la identificación (...) de menores y la captación de su imagen, sino también la información sobre datos colaterales ([...] familia, domicilio [...]) que sean aptos para la identificación.

\section{Menores hijos de padres con notoriedad pública}

Los bienes jurídicos objeto de protección (intimidad, propia imagen) siguen disponiendo en estos casos de tutela legal, si bien es preciso destacar que estas garantías se debilitan proporcionalmente, cuando tienen como límite externo las libertades de información y de expresión, respecto de personas famosas o de relevancia social. La consideración se basa en que estas condiciones (popularidad o relevancia) obligan a soportar cierto riesgo, que no concurre en personas ajenas a dichas situaciones.

A este principio general es preciso hacerle dos matizaciones: en primer lugar, que las personas de pública notoriedad ven reducido el espacio de su intimidad, por esa circunstancia, pero más allá de esto, conservan en su integridad sus derechos en este terreno. Debe recordarse, en segundo lugar, que cuando la imagen divulgada de una de estas personas se acompañe de comentarios o expresiones injuriosas, o cuando se añadan comentarios o cuestiones ajenas e innecesarias, la persona objeto de este tratamiento podrá invocar en todo su rigor la protección de su honor, intimidad e imagen.

Podría pensarse que aquella relativización de la protección y sus matizaciones alcanzan a los menores y no es cierto. Sólo son aplicables a los progenitores, nunca a sus hijos. Los hijos menores de famosos, son solamente menores, excluidos de la curiosidad ajena, cualquiera que sea la actividad de sus padres y el grado de dejación que hayan hecho de sus derechos. Aquellos casos en que una persona explote el relato de su intimidad e incluya en ello a menores, deben ser objeto de tratamiento por el Ministerio Fiscal, de acuerdo con la protección legal del interés superior del menor.

También puede ser objeto de acciones fiscales el acoso o seguimiento periodístico del personaje famoso, cuando se encuentra acompañado por hijos menores y se desenvuelve en el espacio de su vida privada. Recordamos la ati- 
nada cita del juez Cooley, la invocación the right to be let alone o derecho a que "nos dejen en paz". Se trata de que el derecho a la intimidad personal otorga una facultad de exclusión que impone a terceros la obligación de abstenerse de intromisiones fuera del ámbito legal.

\section{Responsables de las conductas prohibidas}

Cuando la conducta ilegal se produce en un medio de comunicación es habitual la concurrencia de diversas personas implicadas. Para saber a quién podemos dirigir la correspondiente demanda debemos acudir a las siguientes consideraciones:

La Ley 14/1966, de Prensa e Imprenta, dispone que la responsabilidad civil por actos u omisiones ilícitos (...) será exigible a los autores, directores, editores, impresores e importadores o distribuidores (...) con carácter solidario. La enumeración es amplia, pero es que a cada uno podemos imaginar su tanto de culpa por las conductas que desempeñan. La aplicación de la responsabilidad sigue lo que se llama el procedimiento "en cascada", es decir de arriba abajo y sucesivamente. El principio de solidaridad es una garantía para el perjudicado, ya que puede demandar a cualquiera de los responsables citados, sin necesidad de hacerlo a todos ellos.

\section{Internet y las telecomunicaciones}

Quiero concluir estas líneas con la alusión con la que comencé, al mundo de las comunicaciones en su versión contemporánea. La enorme potencialidad de estas tecnologías les otorga innumerables ventajas, pero trae consigo, también, la posibilidad de desembocar en comportamientos antijurídicos.

La Ley 34/2002, de servicios de la sociedad de la información y del correo electrónico, recoge entre sus objetivos preferentes la protección de la juventud y de la infancia. Impone a los prestadores de servicios la responsabilidad por los contenidos de páginas web en su elaboración o simplemente por su transmisión, pudiendo ser requeridos a depurar el contenido lesivo a los menores e incluso a la suspensión de la transmisión.

Ligado inseparablemente con el uso de la red, para obtener o emitir información, se encuentra el correo electrónico. Permite comunicarse con un alcance y una rapidez hasta ahora imposibles por los medios tradicionales, pero además la mera comunicación puede incorporar archivos de texto, imágenes estáticas o filmadas. La curiosidad y la 
imprudencia de los menores es difícil que pongan los necesarios límites a estas posibilidades. Si utilizamos asociados los dos medios (Internet y correo electrónico) como es habitual su uso, podemos enviar una información que previamente hayamos extraído o intercambiarla con otras personas. Sucede, lamentablemente, que no siempre podemos saber del recto proceder de quien no vemos, no conocemos, ni sabemos cuáles son sus intenciones.

El descubrimiento y uso de Internet, hace tan sólo unas décadas, he defendido siempre, es comparable, en su repercusión cultural, a la aparición de la imprenta, en el siglo XVI. Puede parecerles que exagero, pero tienen algo en común y es el permitir el acceso a la información y a la cultura, por tanto, a la generalidad de las personas. Con la imprenta se pasó de los ejemplares individuales, fruto de la paciencia de los amanuenses, a la reproducción múltiple y la consiguiente difusión del texto. Con Internet se permite el acceso a archivos ingentes de información, desde cualquier punto con conexión, sin ningún límite cuantitativo ni cualitativo. Esta potencialidad encierra, sin embargo, el peligro cuando se maneja por menores, que, si no son instruidos y alertados, pueden perjudicarse gravemente. $Y$ esto es lamentablemente muy frecuente. Déjenme que concluya acordándome de aquellos preciosos versos de Gil de Biedma: "Que la vida iba en serio uno lo empieza a comprender más tarde -como todos los jóvenes, yo vine a llevarme la vida por delante...-".

Mucha atención a la necesaria protección que les debemos a los niños. Son nuestro futuro. 